\title{
Research on Development and Future Potential of Africa Economy
}

\author{
Chengyishen Yang*
}

\author{
Depu Foreign Language School, Chongqing, China \\ *Corresponding author. Email: guanghua.ren@gecacademy.cn
}

\begin{abstract}
The development potential and the abundant resources in Africa have attracted a lot of foreign attention and gained a lot of FDI. However, that because of the Covid-19, that many countries have been affected and fallen into a recession. Africa was also influenced so that some people have doubted that whether Africa has the potential to develop its economy. This paper researched Africa's s potential through three parts, which is the economy, that Africa has experienced a good development of GDP after 1960. Second is the politics and the religions, it shows that some religions might affect the policies to be successfully carried out. The third is the infrastructure and resources which Africa still needs a lot of construction on the basic infrastructure and many resources can be a product for trade. Therefore, Africa still has the potential to develop its economy, but it will have many problems during this time.
\end{abstract}

Keywords: GDP, Infrastructure, Politics, Africa

\section{INTRODUCTION}

At the end of 2019, there appears a new virus that has never been seen before which is called COVID-19. When it comes out it has a very quick speed to spread. The patient suffered a lot, so most of the government decide to lock down the city for a while. This means that many of the companies or offline businesses will be closed to slow down the spread speed of COVID-19. For example, the convenience store or restaurant will be forced closure. This means that this kind of business cannot make any contribution during this period like profits. So this will affect the economy of a country that the consumption and aggregate supply will decrease, and that the real GDP will lose a lot. This will likely to cause a slow down of the economic growth or even gets a recession. This also happened in the country, Africa. That Africa's country started in 1960 , most of them experience an economic growth, which has the increase of GDP. For example, the Nigeria, that have the GDP in 1961 of 4,466,452,536 dollar, in 2000 the number increase to $69,429,049,664$ dollar, in 2019 it comes to $537,709,850,805$ dollar. This means that the country is experiencing economic growth, and it has fast economic development however that the COVID-19 comes out and affects a lot to the economy. That a large amount of close of the business causes very high unemployment to these Africa countries. Which lead to a recession of the country's economy. Now comes out a problem, that is there any hope for Africa to again develop their economy. It should be considered in many parts. Africa's countries are hailed as mineral wealth places. It has a very large share of the world's mineral resources includes coal, petroleum, natural gas, uranium, radium, and so on. For example, that Africa has about one-fourth of the world's reserves of bauxite, the chief aluminum ore, and half of the world reserves of cobalt can be found in the Democratic Republic of the Congo. However, that many resources in Africa are rarely considered mineable resources. So that many resources are not efficiently extracted. However, it is shown that Africa country has this potential to grow their economy, but it has many existing problems. So, my topic is how can Africa develop their economy.

This paper will mention three parts to find out the solutions to the Africa economy. First is the economic situation, second is the politics and religions, third is the infrastructure and resources.

\section{ECONOMY SITUATION}

Porta and Shleifer had done research on the economy of Africa, but mainly in the area of unofficial economy. That they examined the productivity of informal enterprises that are not registered with the 
government. Field surveys and World Bank companylevel data were used in 24 African countries. They found productivity. If it compares small formal enterprises with informal enterprises, it will rise sharply and rapidly with the expansion of enterprise-scale regular companies. Crucially, informal enterprises seem to be qualitatively different from formal enterprises: they have a small scale, production to order, run by managers with low human capital, no channels for external financing, don't advertise their products, and sell cash to most informal customers. And therefore, the market position occupied by enterprises is quite different from that of formal enterprises, and they rarely become formal enterprises, because there is little demand for their products in the formal sector [1]. Naude and Krugell had done research on geography and the institution as determinants of foreign direct investment in Africa. And they use the panel data to find the result. For example, it uses the model of FDI and suggests the appropriate way to use this equation. And gives us the information on how to estimate this FDI model. Moreover, it talks about the identity of the role that the institution act on to affect the FDI and also the geography and suggests the importance of those two factors. And in conclusion, Africa is the region with the worst economic growth record in the past 30 years. In Africa, due to the low level of domestic investment and savings, the contribution of development assistance is also declining. Attracting more foreign direct investment is particularly useful to stimulate economic growth [2]. Aker had done the research on the mobile phone use and economic development of Africa, which uses data related to the mobile phone, and the increase of the economy. It through the data Number of Cell Phone Subscribers and Cell Phone Coverage in SubSaharan, Summary Statistics of Mobile Phone Adoption and Use in Kenya, Adoption and Use of Mobile Phones and Mobile Phones, Search Costs, Arbitrage, and Welfare and Evolution of Cell Phone Market Structure in Africa to find out. And the data shows that consumers and producers own mobile phone can improve their welfare in a developing country. The increase of the coverage of people have the mobile phone have benefited the consumer and prices welfare, and it is also likely to bring the economic development. Which mobile phone represents will have change from the elite status to the necessity for adults. As the decrease for the price of the mobile phone there will have a push to the innovation, like solar-powered phones. Now the challenge is about the complementary to the public goods and development of economy [3]. Moses and Oketch have done research on the determinants of human capital formation and economic growth in African countries. They find the rapid increase of the economy and improvement of the living standards have benefited most of the countries in the world but except Africa. This is because of the Civil war, war and other factors are rampant, corruption is related to the poor economic performance of the African region in the international community. So the paper has discussed the role of human capital in improving the economic development of the region. The researchers use the theory of endogenous growth theory to explain the process of human capital formation and how does this theory determine economic growth and development. The result is if Africa wants to develop their economy, both the human capital and physical capital of high investment are necessary [4].

The Africa country always experiences a large increase in the GDP from the 1960s. Since 2000 China's Africa relations have developed rapidly, and China's direct investment in Africa has increased nearly 40 times in nine years. How to correctly view the nature of China's direct investment in Africa and study the possible impact of these capital inflowson the economy of African host countries is a hot issue in the international discussion. Based on the endogenous growth theory, this paper establishes an econometric model, makes an econometric analysis on the impact of China's direct investment on African economic growth through cross-sectional data and time-series data, and makes a regional comparison in combination with the actual development of various regions in Africa. It is found that there is a positive correlation between China's direct investment and African economic growth. China's direct investment mainly promotes the economic growth of African host countries through technological progress. There is a long-term stable relationship between the two, but the role of human capital in African host countries has not played a role in promoting the country to absorb technological progress, Therefore, China's direct investment has a more long-term positive effect on African economic growth than direct aid.

The report released by the African Development Bank in July predicts that Africa's gross domestic product (GDP) will decline by $1.7 \%$ to $3.2 \%$ in 2020 . As of August 20, 54 African countries had diagnosed more than 1.14 million cases and died more than 26000 cases. According to the statistics of the African Center for Disease Control and Prevention, 29countries have declared a state of emergency, 37countries have imposed curfews or closed cities, 43 countries have suspended flights or blocked borders, and more than $80 \%$ of countries have taken measures such as isolated observation, travel restrictions, closing schools and religious Entertainment places, and canceling public gatherings.

Economies with a relatively high degree of diversification show some resilience. Egypt, Ethiopia, Rwanda, Senegal, Uganda and other countries are expected to achieve positive economic growth of $1 \%$ $2 \%$. The major economies in sub-Saharan Africa will generally fall into recession. The economies of South 
Africa, Nigeria and Angola are expected to decline by $8 \%, 5.4 \%$ and $4 \%$ respectively. African oil exporters will suffer a loss of revenue of up to the US $\$ 65$ billion, and GDP is expected to fall by $4.9 \%$. Strict restrictions on international personnel mobility have led to a sharp decline in the income of tourist countries, a loss of at least US $\$ 50$ billion in the whole year, and a decline of about $10 \%$ in GDP. The loss of African aviation industry will reach US $\$ 8.1$ billion, South African Airlines faces the risk of bankruptcy, and Mauritius Airlines has announced the commencement of bankruptcy protection proceedings.

Table 1. The top 5 GDP of Africa countries (Billion)

\begin{tabular}{|c|c|c|c|c|c|}
\hline 1960 & South Africa & Nigeria & Congo & Morocco & Sudan \\
\hline Amount & 7.785 & 4.339 & 3.216 & 2.031 & 1.366 \\
\hline 1970 & South Africa & Nigeria & $\begin{array}{l}\text { The Republic of } \\
\text { Egypt in Arabia }\end{array}$ & Congo & Algeria \\
\hline Amount & 17.99 & 11.01 & 7.647 & 4.918 & 4.705 \\
\hline 1980 & South Africa & Nigeria & Algeria & Morocco & $\begin{array}{l}\text { The Republic of } \\
\text { Egypt in Arabia }\end{array}$ \\
\hline Amount & 82.31 & 63.75 & 42.10 & 21.57 & 21.57 \\
\hline 1990 & South Africa & Algeria & Nigeria & $\begin{array}{l}\text { The Republic of } \\
\text { Egypt in Arabia }\end{array}$ & Morocco \\
\hline Amount & 114.2 & 61.51 & 53.20 & 42.71 & 29.86 \\
\hline 2000 & South Africa & $\begin{array}{l}\text { The Republic of } \\
\text { Egypt in Arabia }\end{array}$ & Nigeria & Algeria & Morocco \\
\hline Amount & 136.4 & 99.78 & 69.39 & 54.75 & 38.87 \\
\hline 2010 & South Africa & Nigeria & $\begin{array}{l}\text { The Republic of } \\
\text { Egypt in Arabia }\end{array}$ & Algeria & Morocco \\
\hline Amount & 367.5 & 356.3 & 215.9 & 158.8 & $93, .19$ \\
\hline 2020 & Nigeria & South Africa & $\begin{array}{l}\text { The Republic of } \\
\text { Egypt in Arabia }\end{array}$ & Algeria & Morocco \\
\hline Amount & 448.1 & 351.4 & 303.2 & 167.0 & 118.7 \\
\hline
\end{tabular}

\section{POLITICS AND RELIGIONS}

Manguvo and Mafuvadze had done the research on the impact of traditional and religious practices on the spread of Ebola in West Africa and time for a strategic shift. And it mainly talks about some parts of the Impact of religion and tradition on transmission of Ebola. For example the institution called Perceived Causation of Diseases and Death, Traditional and Spiritual Healing, Funeral and Burial Practices. And for conclusion is that if it is not culturally or religiously acceptable to a community, it is likely to be resisted, thereby reducing efficiency. In order to improve efficiency. In community prevention programs, traditional leaders should play an important role in monitoring and implementation [5].

Tamarkin had conducted the research on the culture and politics in Africa. And most talk about the Legitimizing Ethnicity, Rehabilitating the Post-Colonial State. That is mentioned a lot about the different cultures and gives some thinking like modernization theory, tribalism and so on. The race is a worldwide social fact; mankind Makes their culture define itself in the community against, but people don't always politicize culture; When we do, it may not necessarily be in pursuit of a reactionary xenophobic mentality and. And it has an investigate of how to use ethnic moral discourse to invent a moral African political order and
The relationship between national cultural identity and culture what is the prospect of political and moral reconstruction in African countries, the political potential of moral concept. The conclusion is that there is no reason for ethnic minorities to make positive contributions Past contributions to the common interest will not do so again future. The racial nature of morality provides the basis for radical moral criticism colonial regime [6].

Hassim has done the research on the gender, social position and feminist politics in South Africa. It is believed that in many aspects, this mobilization process has the effect of strengthening rather than challenging the patriarchal relationship. Ultimately, it is possible to expand the debate to whether feminism has any relevance to the struggle of South African women and the form of indigenous feminism. This paper focuses on this issue and puts forward the concept of women's politics in South Africa from the relationship between women's social status and political identity. It also raises some key issues, namely, the necessity and possibility of establishing a feminist core in the women's movement. He finds policies always have different effects on men and women. The specific needs of women do not have to be taken into account in the formulation of policies [7].

In recent years, the development of political ecology in Africa has shown new characteristics and trends. The 
collision and running in between the form of western style regime and local political inheritance is a main line of African political development. African countries have promoted the integration between the two through self adjustment and improvement, alleviated some chronic diseases in African politics, and positive changes have taken place in multiparty elections, party politics and military government relations. However, the structural contradiction between western style regime and local political culture is difficult to eliminate in the short term. At the same time, with the accelerated transformation of politics, economy and society, the "third term"problem and large-scale social movements in many African countries have an impact on their political stability. The impact of African political transformation is also gradually emerging, and changing and reshaping the relationship between Africa and the outside world.

Today, the institutional arrangement of multi party democracy is a common feature of African politics. For a long time, this Western style foreign system has collided with African traditional political culture and become a structural factor affecting the economic development, stability and unity of African countries. This structural contradiction has become the "Achilles heel" affecting African politics, It has also derived the negative and pessimistic views of the outside world on Africa's political transformation. Practice in recent years shows that although African countries have similar institutional coats, their political development presents a complex and diversified trend. The political development path of 54 African countries is not "patterned" or "single". More importantly, African countries are making efforts to self adjust and reform politically, which not only promotes the integration of foreign systems and local politics, Reduce and restrain the contradictions and conflicts between internal and external political cultures as much as possible, strive to enhance the complementarity between the two, actively explore political ideas and governance modelsin line with national conditions, and emphasize the comprehensive learning and reference of different political development paths in the world, to promote African politics in electoral politics, party politics, military and political relations the mode of national governance has been steadily reformed and developed.

African politics is generally developing in a positive direction, and some political problems that have plagued Africa for a long time have been alleviated, such as the accelerated modernization of the construction of state power, the normalization of the relationship between th government and the army, the reduction of election violence, and the rise of people's sense of identity with the country. However, some new problems have gradually become prominent, including the gap between certain development stages, the political dilemma in the exploration of independent development path, and the influence of external factors.

\section{INFRASTRUCTURE AND RESOURCES}

Calderón had done the research on the infrastructure and growth in Africa. The purpose of this paper is to provide a comprehensive analysis of infrastructure development impact assessment on the growth of African countries. It through the Methodology and have, data shown Infrastructure trends in Africa and infrastructure and productivity growth in African countries to find the result. And it has the conclusion that most of the contributions come from more, not better infrastructure. Countries may gain more from larger foreign exchange reserves infrastructure, not quality existing infrastructure. What's the biggest benefit telephone density, power generation, road network length and road quality. It is a master research of the project. And it has the research on the Influence of Progressive Teachers' Unions in the Formation and Implementation of Outcomes Based Education in South Africa. The purpose of this study is to explore whether the concept of teacher education formulated by the Federation of progressive teachers is in practice. In the 1980 s, South Africa remained influential in the post apartheid era results based education (OBE) [8].

Duflo has done the research on the Child health and family resources in South Africa and the evidence of old age pension schemes. This paper presents a nonparametric evidence. The impact of expanded old age pension schemes on children's health in South Africa. Did the increase of family resources has improved the health status of children. So he did this in four parts to consider, which are South African old age pension scheme, data and descriptive statistics, effect evaluation of social pension and non-parametric evidence on children's health. These non-parametric results show that China extended old age pension scheme. South Africa has led to environmental improvements especially health and nutrition of children, especially children. In addition, these findings have a direct policy impact on the design of public projects. First, direct income transfer to poor families will lead to the increase of human capital of the poor [9].

Spence has done the research of the infrastructure and technical constraints, agricultural development in hot and humid areas and semi humid tropical region of Africa. This paper shows that infrastructure, especially rural roads and in the next 20-30 years, irrigation systems are unlikely to be in place in the humid and sub humid tropics of Africa. This paper talks about the record of the development of infrastructure and economy, an expected background of future economic development in the next 20-30 years, cost of increasing rural road coverage, technology needed in the next 20 30 years, develop appropriate technologies. The conclusion is in order to achieve a considerable rate, 
promote economic growth, provide food security, reduce poverty and promote agricultural development. In the future, the growth rate must be greatly increased. Due to limited land resources, expected high population growth rate and land labor ratio, it is expected that Asia's carbon emissions will fall to the current level by 2020. Now, alternative strategies must also be adopted in Africa. What appropriate technology research should focus on Sustainable rain fed production systems[10].

The infrastructure development still have many problems during the construction for example Morocco: transport and renewable energy projects performed well.

Ghana: the growth of short-term construction slows down ,Cameroon: the feasibility and financing of the extension of the Grand Eweng hydropower project ,Kenya: freezing expenditure and combating corruption bring downward risks to Kenya's infrastructure industry.

Compared with the rest of the world, infrastructure construction in Africa lags behind. According to the business environment index of infrastructure market in sub Saharan Africa released by international business watch (BMI) at the end of September 2013, the business environment index of infrastructure market in sub Saharan Africa is low, the regional average value of comprehensive evaluation is only 44.5, and the comprehensive evaluation of high Ghana is only 53.8. Moreover, most of the countries with high business environment index in infrastructure market are southern African countries, while those in eastern Africa are low.

On the one hand, judging from the development of various fields of infrastructure construction in Africa, infrastructure construction in Africa is seriously insufficient. First, in terms of transportation, at present, the area of the African continent is $23 \%$ of the total land area of the world, but its total railway length accounts for only $7 \%$ of the total railway length of the world, and 13 of the 54 countries in Africa do not have railways. The density of ordinary roads and highways in Africa is one fourth and one tenth of the world average respectively. Among them, the railway density and highway density of BRICs countries (Brazil, Russia, India and China) are 4.9 times and 2.3 times that of Africa respectively. According to the statistics of the African Development Bank, the transportation cost of the African continent is $63 \%$ higher than that of developed countries, accounting for $30-50 \%$ of its total exports, and the proportion of 16 landlocked countries (Zimbabwe, South Sudan, Mali, Niger, etc.) is as high as $75 \%$.

Secondly, in terms of power, according to the Standard Chartered Bank Group report, about 50\% of the countries in the African continent are seriously short of power, and the power price is 23 times higher than that in Asia. The electricity consumption of BRIC countries is 2.4 times higher than that of 54 African countries. Third, in terms of water resources, according to the statistics of the African Development Bank, $40 \%$ of African residents lack safe drinking water. On March 3, 2014, the water resources organization said that millions of residents in southern Africa still live without clean drinking water, public toilets and other public health facilities. fourth, in terms of communication, Africa has the lowest penetration rate of telephone and Internet in the world. On May 5, 2014, the International Telecommunication Union released the development forecast of the communication industry in 2014. It shows that although the fixed broadband users in Africa maintained a double-digit growth momentum from 2010 to 2013, they accounted for less than $0.5 \%$ of the global total. The penetration rate of mobile broadband in Africa was $19 \%$, and the Internet connection was only $10 \%$.

Therefore, Africa has a lot of problems with the infrastructure but if it covers this out it will experience a large benefit to it's economy.

Table 2. Infrastructure projects and financing scale in Africa ( $\$ 1$ billion)

\begin{tabular}{llllllllllll}
\hline & 2003 & 2004 & 2005 & 2006 & 2007 & 2008 & 2009 & 2010 & 2011 & 2012 & 2013 \\
\hline Project number & 5 & 6 & 8 & 7 & 9 & 12 & 18 & 15 & 15 & 23 & 35 \\
\hline Project finance & 12 & 28 & 28 & 45 & 92 & 43 & 58 & 47 & 58 & 89 & 101 \\
\hline
\end{tabular}

\section{CONCLUSION}

As mentioned above, this study has discussed the potential for the further development of Africa. Although Africa increased their GDP over many years, it still exists many problems. First, it may have lack of the capital investment, because that development of the economy includes the most important part is investing the infrastructure project. The second is the religions should be considered when publishing a policy or using the policy to restrict some religions. However that Africa is the wealth places which exists many mineral resources so it can be used to trade with other countries to exchange capital. And it may accept the help from other countries to construct their basic facilities. Moreover, it has more hope to 
develop it's economy. Therefore, it should be concluded that Africa has the potential to enhance it's economy.

\section{REFERENCES}

[1] Porta, R. L., \& Shleifer, A. (2011). The Unofficial Economy in Africa.

[2] Naudé, W. A., \& Krugell, W. F. (2007). Investigating geography and institutions as determinants of foreign direct investment in Africa using panel data. Applied Economics, 39(10), $1223-1233$.

[3] Akerv, J. C., \& Mbiti, I. M. (2011). Mobile phones and economic development in Africa. Operations Research, 51(3), 273-276.

[4] Moses, O., \& Oketch. (2006). Determinants of human capital formation and economic growth of african countries. Economics of Education Review.

[5] Manguvo, A., \& Mafuvadze, B. (2015). The impact of traditional and religious practices on the spread of ebola in west africa: time for a strategic shift. Pan African Medical Journal, 22 Suppl 1(Supp 1), 9.

[6] Tamarkin, M. (1996). Culture and politics in Africa: Legitimizing ethnicity, rehabilitating the post-colonial state. Nationalism and Ethnic Politics, 2(3), 360-380.

[7] Hassim, S. (1991). Gender, social location and feminist politics in south africa. transformation.

[8] Calderon, C. (2009). Infrastructure and growth in africa. Policy Research Working Paper Series.

[9] Duflo, E. (2000). Child Health and Household Resources in South Africa: Evidence from the Old Age Pension Program. American Economic Review, 90(2), 393-398.

[10] Spencer, D. S. (1996). Infrastructure and Technology Constraints to Agricultural Development in the Humid and Subhumid Tropics of Africa. African Development Review, 8(2), 6893. 